\title{
Effect of Aluminium Powder on Light-weight Aerated Concrete Properties
}

\author{
Lam Tang Van ${ }^{1,2, *}$, Dien Vu Kim ${ }^{1}$, Hung Ngo Xuan ${ }^{1,2}$, Tho Vu Dinh ${ }^{1}$, Boris Bulgakov ${ }^{1}$ and \\ Sophia Bazhenova ${ }^{1}$ \\ ${ }^{1}$ Moscow State University of Civil Engineering, Yaroslavskoe Shosse, 26, Moscow, 129337, Russia \\ ${ }^{2}$ Hanoi University of Mining and Geology, 18 Pho Yen, Duc Thang, Bac Tu Liem, Hanoi, Vietnam
}

\begin{abstract}
Light-weight aerated concrete (LAC) is produced by making LAC involves the addition of a gas-forming admixture like aluminium powder (AP) to a wet mortar mixture. In concrete during curing, AP will react with the calcium hydroxide in the mixture to form hydrogen. The amount of gas-forming is dependent on the mechanical properties requirements. The aim of the current work was to investigate the properties of aerated concrete (AC) containing $30 \%$ fly ash and various AP content, including dry density, porosity and modulus of elasticity, as well as strengths of test specimens. The results of this study showed that when AP content increased, the density of AC decreased, but its porosity increased. Whereas an increase in the amount of AP caused a decrease in both the compressive strength, tensile strength and the modulus of elasticity of ACspecimens. The investigation of newly modified AC through combination of local by-product in Vietnam would decrease the content of Portland cement was used and as well as reduce the amounts of ash and slag TPP as well as industrial waste thrown at a landfill. Therefore, assisting the thermoelectric power plants to be more environmentally friendly in the future.
\end{abstract}

\section{Introduction}

Vietnam is one of the large thermoelectric power producers, has been generating many agroindustrial waste materials like fly ash (FA), slag and bottom ash from the thermoelectric power plants (TPP). The yearly content of agro-industrial waste materials is about 150 million tons in this country. In details, blast-furnace slags are from 45 to 60 million tons, while slag and ash TPP is more than 50 million tons [1,2].

Especially 2016, only TPP "Vung Ang" was produced about 3 thousand tons of fly and bottom ash and slag materials on the daily. Furthermore, a colossal number of combustible gases and solid particles, which were formed as well, as a result of the combustion of solid-fuels at these TPP, have caused serious air and water environmental pollution in some provinces of Vietnam [3, 4].

In recent years, the recycling of agricultural and industrial waste as modified additives for concrete and mortar mixtures both reduces capital investments and production cost in

\footnotetext{
* Corresponding author: lamvantang@gmail.com
} 
the production of construction materials products.. In addition, assisting the thermoelectric power industry to be more environmentally friendly $[5,6]$.

As we know, different aerated concrete (AC) types are produced by addition or generating bubbles voids within the mortar mixes and the voids or cell structure having a homogeneous distribution in the cement and fine sand mix. The gas-forming admixture produces the concrete of higher porosity. The introduction of a gas-forming material from aluminium powder (AP) reacts with the $\mathrm{Ca}(\mathrm{OH})_{2}$ formed on the hydration of Portland cement to obtained hydrogen gas and a final result to produce the large pores structure of the concrete. Nowadays, light-weight aerated concrete is proven as a very diverse material that has created great investigations and large huge demand in a wide range of different project types. It is not only used to make the heat and sound insulation materials $[7,8]$ but is also in fire retardant material $[9,10]$. Light-weight aerated concrete was used to decrease the dead load and earthquake loads, as well as the size of building structures. Thus, the foundations of the building become more economical and the construction costs were decreased $[11,12]$. Typical light-weight concretes have an oven average dry density range from 300 to $2000 \mathrm{~kg} / \mathrm{m}^{3}$, and its compressive strength for a cube sample at age 28-day from about some MPa to $60 \mathrm{MPa}$ [13].

Several sciences researches have been carried out regarding the effect of aluminium powder (AP) content on the strengths of AC-samples $[14,15]$. Some works into the dry density and pores structure of aerated concrete have also been carried out [16-18]. Besides that, published studies [19, 20] have identified the influence of expanded polystyrene beads on the lightweight concrete properties.

Because the main objective of present investigation was to study the influences of aluminium powder amount on properties of light-weight aerated concrete containing $30 \%$ mass of fly ash, which is intended for precast lightweight concrete panels for new construction of the High-Rise buildings.

\section{Experimental procedures}

\subsection{Materials}

a). Quartz sand (QS) sourced original from "Lo river" in the North of Vietnam was used as fine aggregate in light-weight concrete mixtures. The physical properties of the fine aggregate are presented in Table 1.

Table 1. The physical properties of fine aggregate.

\begin{tabular}{|c|c|c|c|c|c|}
\hline $\begin{array}{c}\text { Size of } \\
\text { aggregate }(\mathrm{mm})\end{array}$ & $\begin{array}{c}\text { Loose density } \\
\left(\mathrm{kg} / \mathrm{m}^{3}\right)\end{array}$ & $\begin{array}{c}\text { Dry density } \\
\left(\mathrm{g} / \mathrm{cm}^{3}\right)\end{array}$ & $\begin{array}{c}\text { Saturated density } \\
\left(\mathrm{kg} / \mathrm{m}^{3}\right)\end{array}$ & $\begin{array}{c}\text { Water absorption } \\
(\%)\end{array}$ & $\begin{array}{c}\text { Fineness } \\
\text { modulus }\end{array}$ \\
\hline $0.15 \div 5$ & 1490 & 2.65 & 2682 & 0.50 & 3.1 \\
\hline
\end{tabular}

b). The binder was used in this work including ordinary Portland cement and Class F- Fly ash. The cement used was locally Grade 40-Portland cement (PC) (Figure 1a), which manufactured at "But Son" factory in Vietnam with a specific weight of $3.15 \mathrm{~g} / \mathrm{cm}^{3}$. Whereas, class F - Fly Ash (FA) used (Figure 1b) in this investigation was obtained from TPP "Vung Ang" (Vietnam). The basic characteristics of PC and FA are given in Tables 2 and 3, respectively.

Table 2. The characteristics of PC "But Son".

\begin{tabular}{|c|c|c|c|c|c|c|c|c|}
\hline $\begin{array}{c}\text { Specific } \\
\text { weight } \\
\left(\mathrm{g} / \mathrm{cm}^{3}\right)\end{array}$ & $\begin{array}{c}\text { Surface } \\
\text { area } \\
\left(\mathrm{cm}^{2} / \mathrm{g}\right)\end{array}$ & $\begin{array}{c}\text { Pasing } \\
\text { sieve 10 } \\
\mu \mathrm{m}(\%)\end{array}$ & \multicolumn{2}{|c|}{ Time of setting } & \multicolumn{3}{|c|}{ Compressive strength (MPa) } & $\begin{array}{c}\text { Standard } \\
\text { consistency } \\
(\%)\end{array}$ \\
\hline 3.15 & 3650 & 18 & 145 & 250 & 30.5 & 41.8 & 51.6 & 29.5 \\
\hline
\end{tabular}


Table 3. The physical properties of FA "Vung Ang".

\begin{tabular}{|c|c|c|c|}
\hline $\begin{array}{c}\text { Specific weight } \\
\left(\mathrm{g} / \mathrm{cm}^{3}\right)\end{array}$ & $\begin{array}{c}\text { Unit weight of natural } \\
\text { porous state }\left(\mathrm{kg} / \mathrm{cm}^{3}\right)\end{array}$ & Surface area $\left(\mathrm{cm}^{2} / \mathrm{g}\right)$ & $\begin{array}{c}\text { Passing sieve } 10 \mu \mathrm{m} \\
(\%)\end{array}$ \\
\hline 2.48 & 850 & 3850 & 15 \\
\hline
\end{tabular}

The experimental results of physical compositions of both PC "But Son" and FA are presented in Tables 4 .

Table 4. The chemical compositions of PC "But Son" and FA "Vung Ang".

\begin{tabular}{|c|c|c|c|c|c|c|c|c|c|c|c|}
\hline $\begin{array}{c}\text { Types of } \\
\text { Materials }\end{array}$ & $\mathrm{SiO}_{2}$ & $\mathrm{Al}_{2} \mathrm{O}_{3}$ & $\mathrm{Fe}_{2} \mathrm{O}_{3}$ & $\mathrm{SO}_{3}$ & $\mathrm{~K}_{2} \mathrm{O}$ & $\mathrm{Na} 2 \mathrm{O}$ & $\mathrm{MgO}$ & $\mathrm{CaO}$ & $\mathrm{P}_{2} \mathrm{O}_{5}$ & $\begin{array}{c}\text { Loss on } \\
\text { ignition }\end{array}$ & Other \\
\hline $\begin{array}{c}\text { Portland } \\
\text { cement }\end{array}$ & 21.87 & 4.12 & 2.55 & 2.05 & 1.08 & 1.12 & 1.15 & 61.56 & - & 2.75 & 1.75 \\
\hline Fly ash & 62.34 & 21.35 & 5.72 & 2.45 & 1.25 & 1.23 & 0.55 & 2.05 & 1.04 & 2.02 & 0 \\
\hline
\end{tabular}

c). Aluminium powder (AP) (Figure 1c) sourced from Vietnam was used as a gas foaming agent in the current study. The volume increase of concrete mixtures is dependent upon the content of aluminium powder that is introduced to react with the calcium hydroxide in the mixtures. This reaction is shown in the following equations $[14,15]$ :

$\begin{array}{cccc}2 \mathrm{Al} \\ \begin{array}{c}\text { Aluminium } \\ \text { Powder }\end{array}\end{array} \quad \begin{gathered}3 \mathrm{Ca}(\mathrm{OH})_{2} \\ \text { (Calcium } \\ \text { Hydroxide) }\end{gathered}+6 \mathrm{H}_{2} \mathrm{O} \rightarrow \begin{gathered}3 \mathrm{CaO}_{2} \mathrm{Al}_{2} \mathrm{O}_{3} \cdot 6 \mathrm{H}_{2} \mathrm{O} \\ \text { (Tricalcium } \\ \text { Hydrate) }\end{gathered}+\begin{gathered}3 \mathrm{H}_{2} \\ \text { (Hydrogen) }\end{gathered}$

The main characteristics of aluminium powder were given in Table 5.

Table 5. The basic properties of the aluminium powder.

\begin{tabular}{|c|c|c|}
\hline No & Main characteristics & Values of indicators \\
\hline 1 & Appearance & Silvery white \\
\hline 2 & Purity $(\%)$ & $\geq 0.99$ \\
\hline 3 & Soluble organic substance $(\%)$ & $\leq 4.0$ \\
\hline 4 & Volatiles $\left(105^{\circ} \mathrm{C}, \%\right)$ & $50-75$ \\
\hline 5 & Particle size $(\mu \mathrm{m})$ & Soluble in acid, alkali, not in the water \\
\hline 6 & Solubility &
\end{tabular}

d). Type-F superplasticizer (SP5000) "SR-5000 SilkRoad" (Hanoi-Korea co., Ltd., Vietnam) with a specific gravity of $1.1 \mathrm{~g} / \mathrm{cm}^{3}$ was used to reduce the content of water in the preparation of the concrete mixes.

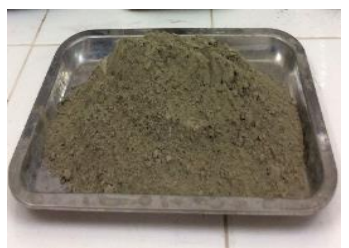

(a)

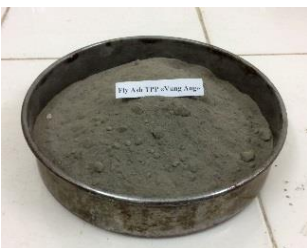

(b)

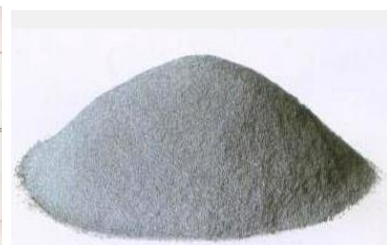

(c)

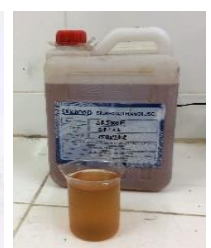

(d)

Fig. 1. (a) - Portland cement "But Son", (b) - Fly ash "Vung Ang", (c) - Aluminium powder and (d) Superplasticizer SR 5000F "SilkRoad".

e). In the present investigation, mixing water (W) is ordinary tap water, which was used throughout preparation of concrete-patterns.

\subsection{Mixture proportions and samples preparation}

Based on the results of researches $[18,23]$ and in the case of this study, the initial ratios of used materials by mass of PC in the mixes for the AC-samples are presented in Table 6. 
Table 6. The mixing ratios of raw materials.

\begin{tabular}{|c|c|c|c|c|c|c|}
\hline Ratios of material & $\frac{Q S}{P C}$ & $\frac{F A}{P C}$ & $\frac{\text { SP5000 }}{P C}$ & $\frac{\mathrm{W}}{P C}$ & $\frac{A P}{P C}$ & $\begin{array}{c}\text { Volume of air in } \\
\text { concrete }\end{array}$ \\
\hline Aerated Concrete & 2 & 0.3 & 0.015 & 0.5 & $0 \div 0.01$ & $2 \%$ \\
\hline
\end{tabular}

According to data from Table 6, a total number of five $\mathrm{AC}$ mixtures with varying contents of aluminium powder were prepared for current research. A control mix concrete (M-1) had a composition of 1 (cement) : 2 (quartz sand) and doesn't AP contain. The AP mixtures were added with $0.25 \%, 0.5 \%, 0.75 \%$ and $1 \%$ by weight of Portland cement in tested concrete mixtures. The W/PC, FA/PC and SP5000/PC ratios, respectively, of $0.5,0.3$ and 0.015 were kept constant for all AC-mixes and no adjustment to the amount of water is made for all mixes in the preparation of light-weight concrete specimens. Further details about five mixtures of aerated concrete are illustrated in Table 7.

Table 7. Mixture proportions of light-weight aerated concrete.

\begin{tabular}{|c|c|c|c|c|c|c|c|}
\hline \multirow{2}{*}{ Mixes No. } & \multirow{2}{*}{ AP (\%) } & \multicolumn{7}{|c|}{ Concrete mixtures (kg) } \\
\cline { 3 - 8 } & & PC & QS & FA & SP5000 & AP & W \\
\hline M-1 & 0 (Control mixture) & 400 & 800 & 120 & 6 & 0.0 & 200 \\
\hline M-2 & 0.25 & 400 & 800 & 120 & 6 & 1.0 & 200 \\
\hline M-3 & 0.50 & 400 & 800 & 120 & 6 & 2.0 & 200 \\
\hline M-4 & 0.75 & 400 & 800 & 120 & 6 & 3.0 & 200 \\
\hline M-5 & 1 & 400 & 800 & 120 & 6 & 4.0 & 200 \\
\hline
\end{tabular}

\subsection{Test procedures}

In this work, first, PC, FA and QS were mixed together for 5 minutes. Then AP was added into this mixture and mixed for 2 minutes. Next, water and SP5000 also were mixed together to obtain a solution. Finally, the solution containing water and superplasticizer was added to the concrete mixer and mixed for 3 minutes to obtain the concrete mixture for the production of aerated concrete specimens.

The mechanical properties of light-weight aerated concrete were measured by a fully automatic, constant stress testing machine (Controls Advantest 9, Italia) (Figure 2) under a loading rate from $500 \mathrm{~N} / \mathrm{s}$ to $1000 \mathrm{~N} / \mathrm{s}$.

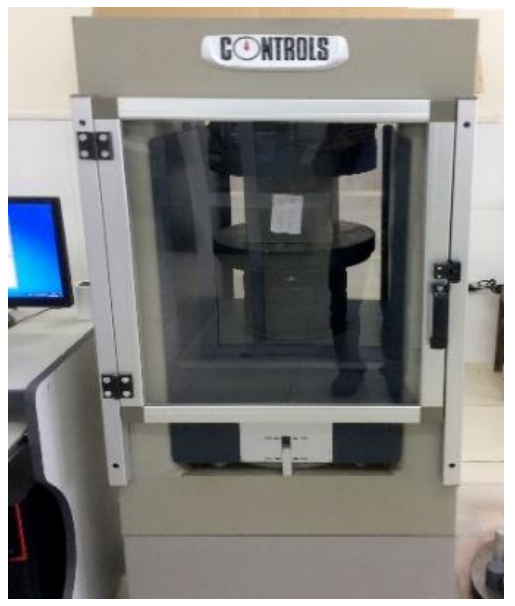

Fig. 2. Compressive strength test of aerated concrete specimens.

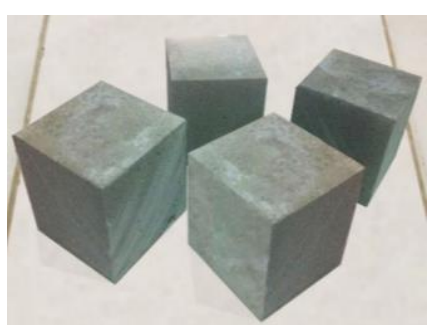

Fig. 3. The aerated concrete test specimens. 


\subsubsection{Density and porosity of the aerated concrete}

The average dry density of the AC-sample was identified according to standard BS EN 992 [21], while the porosity of the AC was determined by water soaking methods [22, 23].

\subsubsection{Compressive and flexural strengths of aerated concrete specimens}

The compressive strength ( $\left.f_{c s}, M P a\right)$ of aerated concrete was identified by a $150 \times 150 \times 150$ mm cube sample (Figure 3) by GOST 10180-2012 (Russian standard) at 28 days.

The flexural strength ( $\mathrm{f}_{\mathrm{fs}}, \mathrm{MPa}$ ) of the AC samples was determined in accordance with standard ASTM C 78 on the $100 \times 100 \times 400 \mathrm{~mm}$ prismatic patterns and using the method of third point loading. The flexural strength of concrete was measured at age 28 days.

\subsubsection{Modulus of elasticity of aerated concrete}

Concrete cylinder specimens with the dimension (diameter of $100 \mathrm{~mm}$ and length of $200 \mathrm{~mm}$ ) were used to identify modulus of elasticity (E, MPa) at the age of 28 days according to BS EN 1352 [24].

All aerated concrete samples in this study were maintained in static for 24 hours (after 1 day) and next subjected to standard maintenance (temperature of $20 \pm 5 \mathrm{oC}$ and humidity $>90 \%$ ) until age 28 days.

\section{Results and Discussion}

The obtained results of the basic characteristics of the light-weight aerated concrete containing $30 \%$ fly ash and different aluminium power content are given details in Table 8 .

Table 8. The properties of the light-weight aerated concrete.

\begin{tabular}{|c|c|c|c|c|c|c|c|c|c|c|}
\hline \multirow{2}{*}{$\begin{array}{l}\text { Mix } \\
\text { No. }\end{array}$} & \multirow{2}{*}{$\begin{array}{l}\text { AP } \\
(\%)\end{array}$} & \multirow{2}{*}{$\begin{array}{c}\text { Average } \\
\text { density } \\
\left(\mathrm{kg} / \mathrm{m}^{3}\right)\end{array}$} & \multirow{2}{*}{$\begin{array}{c}\text { Porosity } \\
(\%)\end{array}$} & \multicolumn{4}{|c|}{ Compressive strength (MPa) } & \multirow{2}{*}{$\begin{array}{c}\text { Flexural } \\
\text { strength at } \\
28 \text { days } \\
(\mathrm{MPa})\end{array}$} & \multirow{2}{*}{$\begin{array}{c}\text { Modulus of } \\
\text { elasticity } \\
\text { (E) at } 28 \\
\text { days (MPa) }\end{array}$} & \multirow{2}{*}{$\frac{E_{1}}{E_{i}}$} \\
\hline & & & & 3-day & 7-day & 14-day & 28-day & & & \\
\hline M-1 & 0 & 2190 & 8.95 & 25.3 & 35.9 & 47.2 & 52.7 & 5.45 & 28.8 & - \\
\hline M-2 & 0.25 & 1840 & 12.35 & 17.5 & 24.1 & 30.0 & 32.6 & 4.6 & 19.7 & 1.46 \\
\hline M-3 & 0.50 & 1780 & 20.14 & 14.6 & 19 & 24.2 & 26.3 & 4.2 & 15.2 & 1.895 \\
\hline M-4 & 0.75 & 1705 & 22.83 & $\begin{array}{l}13.2 \\
\end{array}$ & 17.1 & 21.9 & 23.8 & 3.8 & 10.3 & 2.796 \\
\hline M-5 & 1 & 1485 & 24.44 & 11.0 & 15.1 & 19.2 & 20.5 & 3.2 & 6.5 & 4.43 \\
\hline
\end{tabular}

As the results, the average density and porosity values of test specimens were in the range, respectively, of $1485 \div 2190 \mathrm{~kg} / \mathrm{m}^{3}$ and $8.95 \div 24.44 \%$. As can be observed in Figure 4 , the average density of the AC appears to greatly decrease with an increase in porosity of test specimens. It has been observed that the inclusion of aluminium powder up to $1 \%$ by weight of cement decreases the average density of light-weight aerated concrete to be lower by $32.2 \%$ than control specimens (Mix-1). The results of this work, similar to the results presented from previous researches [8, 16, 19]. According to GOST 25820-2014 (standard of Russian), AC tested is the light-weight concrete with an average density in the range from $500 \mathrm{~kg} / \mathrm{m}^{3}$ to $1850 \mathrm{~kg} / \mathrm{m}^{3}$. Thus, in the case of the current work, the concrete mixtures containing $0.25 \div 1 \%$ content of AP is being considered as lightweight concrete. 


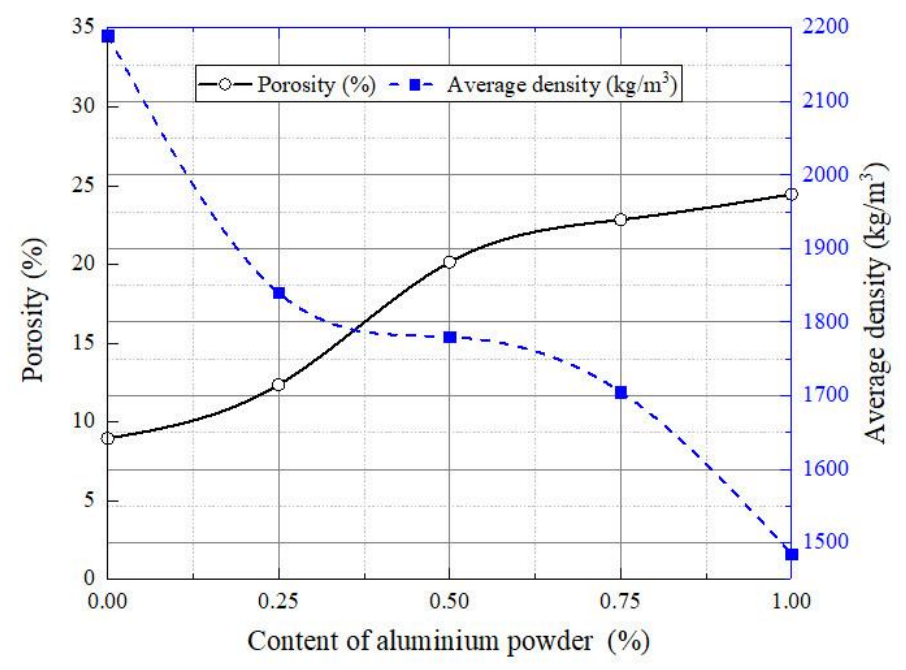

Fig. 4. Effect of aluminium powder content on the average density and porosity of aerated concrete.

The influence of AP amount on the compressive strength at age 28-day and an average density of aerated concrete are illustrated in Figure 5. This figure shows that the increase aluminium powder content for the five concrete mixtures tested reduces not only compressive strength but also the dry density of AC-sample in this experiment.

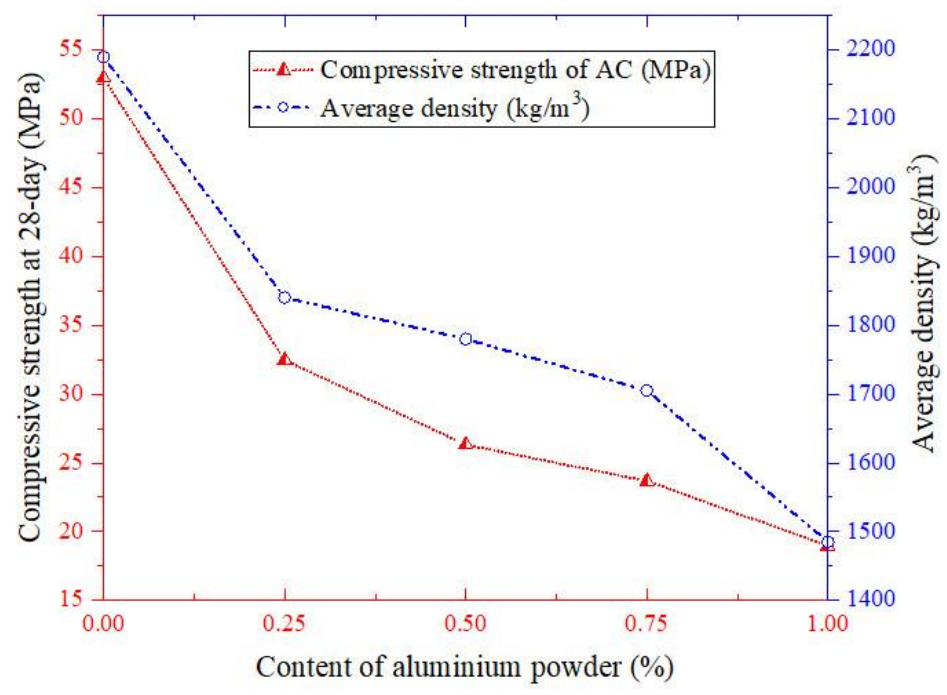

Fig. 5. Effect of aluminium powder content on the compressive strength and average density of ACsample.

Data presented in Table 8 indicates that the test AC-samples achieved the average value of compressive strength in the range of $20.5 \div 52.7 \mathrm{MPa}$ at 28 -day of curing. Whereas the flexural strength and modulus of elasticity values were in the range, respectively, $3.2 \div 5.45$ $\mathrm{MPa}$ and $6.5 \div 28.8 \mathrm{MPa}$ at the same age.

The large value of the compressive strength of test AC-sample containing $30 \%$ fly ash occurs due to the compression of concrete micro-structure when extra secondary $\mathrm{C}-\mathrm{S}-\mathrm{H}$, which are formed through pozzolanic reactions between the amorphous silica $\left(62.34 \% \mathrm{SiO}_{2}\right)$ of $\mathrm{FA}$ and $\mathrm{Ca}(\mathrm{OH})_{2}($ or $\mathrm{CaO})$, the end product of the Portland cement 
- water hydration reaction during concrete curing. Besides, the strength of normal concrete depends on the hydration process and it is lower than these pozzolanicreactions of AC-samples due to lesser content of secondary $\mathrm{C}-\mathrm{S}-\mathrm{H}$ that is responsible for a high-performance concrete, similar to the results presented in a published research [25].

In addition, the results of this investigation were observed that the compressive and flexural strengths values should be correlated with the corresponding aluminium powder content in concrete mixtures. Figure 6 was displayed a good relationship amongst the flexural-compressive strengths of AC-samples and aluminium powder amount.

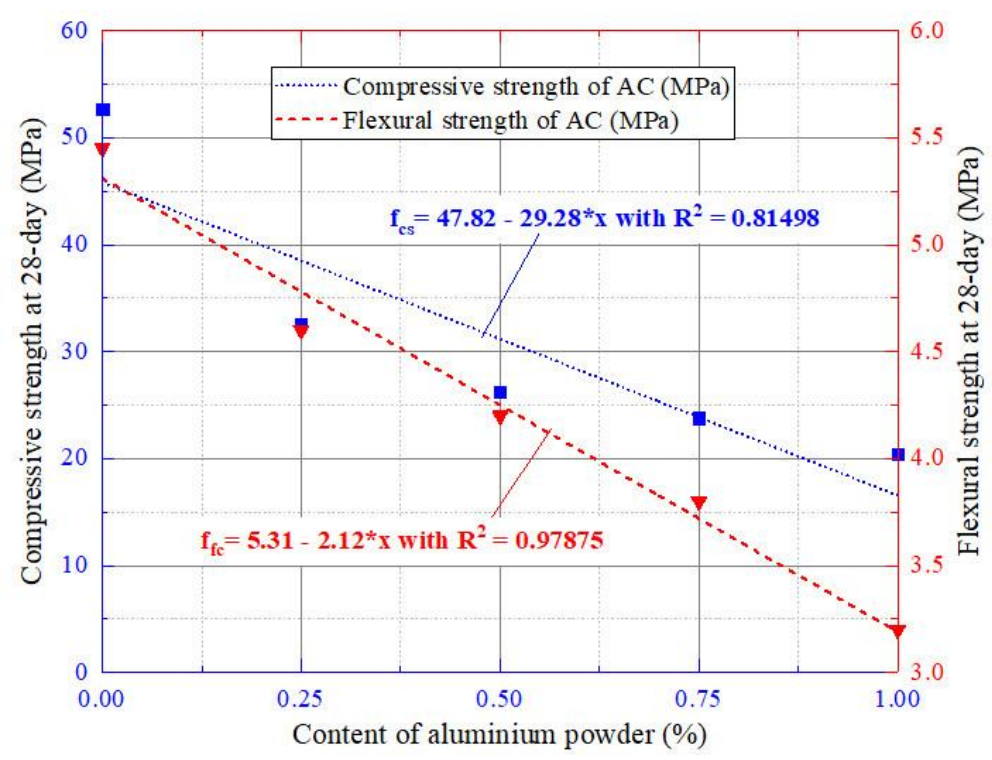

Fig. 6. The fitting relationships between the flexural-compressive strengths of aerated concrete and aluminium powder content.

In this work, to correlate the obtained data from experiments, a linear regression method was applied, resulting in Equations (2) and (3) with a correlation coefficient values $\left(R^{2}\right)$, respectively, of 0.81498 and 0.97875 for the compressive and flexural strength of AC-samples test. They are displayed as the following:

- $\quad$ For the 28-day compressive strength: $f_{c s}=47.82-29.28 * x\left(R^{2}=0.81498\right)$.

- $\quad$ For the 28-day flexural strength: $\mathrm{f}_{\mathrm{fs}}=5.31-2.12 * \mathrm{x}\left(\mathrm{R}^{2}=0.97875\right)$.

where $\mathrm{x}$ signifies the content of aluminium powder $(\%)$ adding in concrete mixtures.

The fitting relationships between the measured 28-day compressive and flexural strength of aerated concrete specimens tested are illustrated in Figure 7 . The quadratic relationships between compressive strength and flexural strength at age 28 day with various AP content $(0 \%, 0.25 \%, 0.5 \%, 0.75 \%$ and $1 \%)$ was shown by equation (4).

$$
f_{c s}=70.92-33.603 *\left(f_{f s}\right)+5.508 *\left(f_{\mathrm{fs}}\right)^{2} \text { where } R^{2}=0.99252
$$




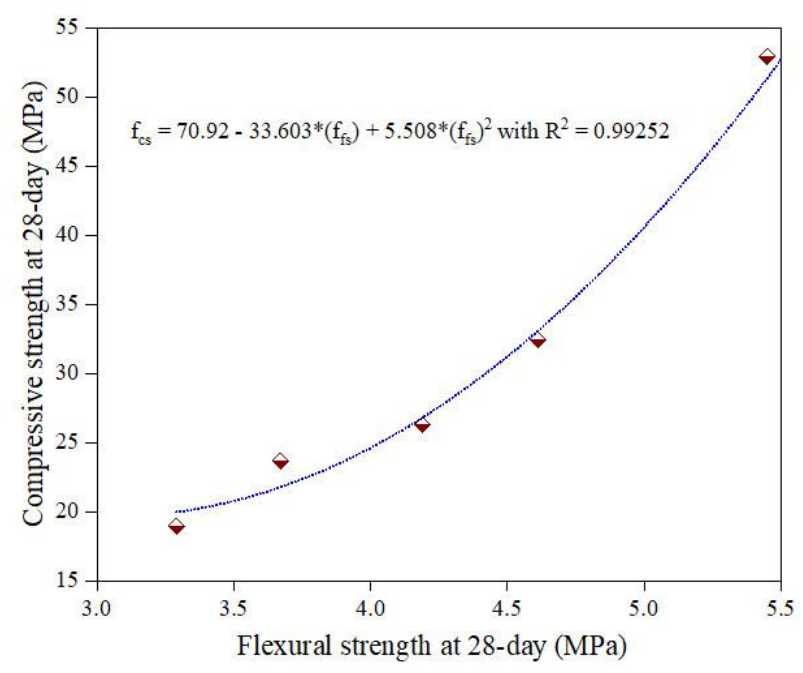

Fig. 7. Relationship between compressive-flexural strengths of lightweight aerated concrete.

Modulus of elasticity is associated with the density of the aerated concrete and mainly affected by the nature of the fine, coarse aggregates and structure of cement stone. In this case, aerated concrete samples have less stiffness due to the AP amount, which caused larger and more pores of structure to be formed and its result is reduced mechanical properties. Furthermore, the AC-samples which are obtained from high AP amount caused a greater loss in the modulus of elasticity than that with lower AP amount.

Data presented in Table 8 also shows that all mixes produced with AP content of $0.25 \%$, $0.5 \%, 0.75 \%$ and $1 \%$ gives lower modulus of elasticity in comparison to the control mixture (Mix-1), respectively, of 1.46, 1.895, 2.796 and 4.43 times.

As can be observed in Figure 8, the fitting relationship between modulus of elasticity and the measured 28-day compressive strength of test aerated concrete was given by a linear regression equation (5).

$$
\mathrm{E}=0.633^{*}\left(\mathrm{f}_{\mathrm{cs}}\right)-3.453 \text { where } \mathrm{R}^{2}=0.93975 \text {. }
$$

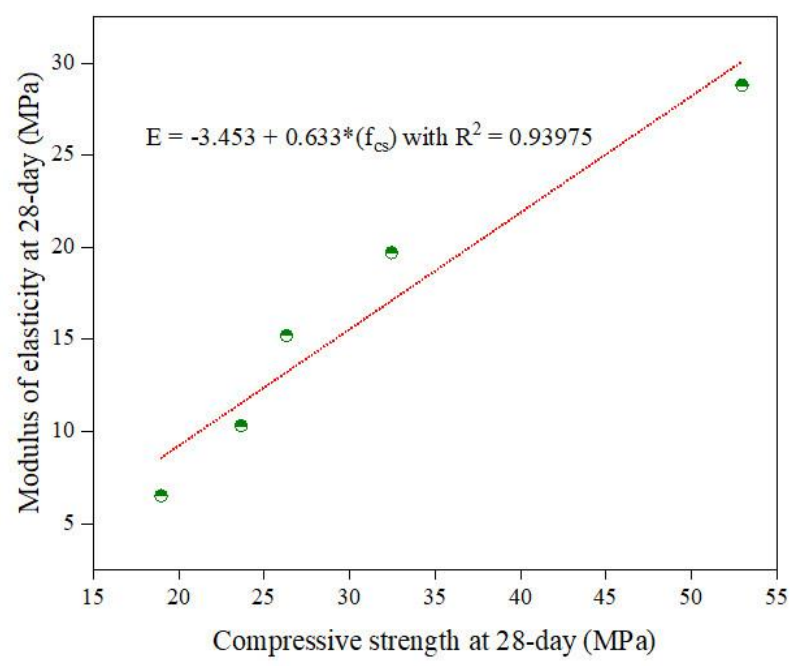

Fig. 8. Correlation between modulus of elasticity and 28-day compressive strength of aerated concrete samples. 
The values $\mathrm{R}^{2}$ of Equation (5) of 0.93975 represents a very strong negative correlation between the two compared parameters of the modulus of elasticity and 28-day compressive strength of AC-samples containing 30\% FA and various content of aluminium powder.

\section{Conclusions and future work}

- The concrete mixtures containing $0.25 \%, 0.5 \%, 0.5 \%$ and $1 \%$ aluminium powder by weight cement have an average density in the range from $1485 \mathrm{~kg} / \mathrm{m}^{3}$ to $1850 \mathrm{~kg} / \mathrm{m}^{3}$, which can be considered as light-weight aerated concrete according to GOST 25820-2014 (Russian standard).

- The increase in aluminium powder content added in test concrete mixtures, its density, strength, and modulus of elasticity decrease, but porosity increase. Aerated concrete samples have less stiffness due to the aluminium powder content, which caused larger and more pores of structure to be formed and its result is reduced mechanical properties of test concrete. The results this word show that aerated concrete containing various aluminium powder content gives lower modulus of elasticity in comparison to the control mixture (M1) from 1.46 to 4.43 times.

- The control concrete samples containing 30\% fly ash achieved a compressive strength value of $52.7 \mathrm{MPa}$ at age 28-day. The large value of the compressive strength of control samples occurs due to the compression of concrete micro-structure when extra secondary $\mathrm{C}-\mathrm{S}-\mathrm{H}$, which is formed through pozzolanic reactions between the amorphous silica of FA and $\mathrm{Ca}(\mathrm{OH})_{2}$, the end product of the Portland cement - water hydration during curing of concrete.

- In the future, the investigation of light-weight aerated concrete with new properties by a combination of local by-product in Vietnam should decrease not only the content of Portland cement was used but also reduces the amounts of fly ash as well as industrial waste thrown at a landfill. Therefore, assisting the thermoelectric power plants in Vietnam to be more environmentally friendly.

The authors greatly appreciate the valuable assistance provided by the fellows of the Department "Technology of Binders and Concretes" at the National Research Moscow State University of Civil Engineering - MGSU (Russian Federation) during this work.

\section{References}

1. Government Office, Conclusions of the Prime Minister to implement the production program of utilization of unburned materials and the use of fly ash, slag and gypsum waste of thermal power plants and chemical plants (TB-VPCP 218. Vietnam) (2013)

2. T.T. Hong, Build. Materi. 06, 25 (2010)

3. T.V. Lam, B.I. Bulgakov, O.V. Aleksandrova, O.A. Larsen, Bulletin BSTU. V.G. Shukhov 6, 06 (2017), https://doi.org/10.12737/article_5926a059214ca0.89600468

4. T.V. Lam, N.X. Hung, B.I. Bulgakov, O.V. Alexandrova, O.A. Larsen, A.Y. Orekhova, A.A. Tyurina, Bulletin BSTU. V.G. Shukhov 8, 19 (2018), https://doi.org/10.12737/article_5b6d58455b5832.12667511

5. V.T. Lam, B.I. Bulgakov, S. Bazhenova, O. Aleksandrova, N.A. Pham, V.D. Tho, E3S. Web. of. Conferences. 33, 02029 (2018), https://doi.org/10.1051/e3sconf/20183302029

6. V.T. Lam, B.I. Bulgakov, O. Aleksandrova, O. Larsen, N.A. Pham, E3S. Web. Of. Conferences. 33, 02030 (2018), https://doi.org/10.1051/e3sconf/20183302030

7. Aidan and et al, Scien. Wor. Of. The. Unive. of. Rus. 48, 9 (2009)

8. A.J. Hamad, Concre. Interna. Jour. Of. Mate. Scien. And. Engin. 2, 2 (2004)

9. N. Narayanan, K.Ramamurthy, Ceme. And. Concr. Compo. 22, 5 (2000) 
10. A. Keyvani1, Intern. Jour. of. Resea. in. Engine. And. Tech. 3, 3 (2014)

11. D. H. Lim, B.H. Oh, Engine. Struct. 21, 10 (1999)

12. O.A. Duzgun, R. Gul, A.C. Aydin, Materi. Lett. 59, 27 (2005)

13. J.H. Mohammed, A.J. Hamad, Techni. Revi. of. Facu. of. Engine. Unive. of. Zul. 37(2), 10 (2014)

14. P. O. Guglielmi and et al, Advan. in Civ. Engine. 201, 6 (2010)

15. I.S. Raj, E. John, A Interna. Jour. of Scien. Engine. and Tech. 3, 11 (2014)

16. K.H. Yang, K.H. Lee, Constr. and. Buil. Mater. 74, 109 (2015)

17. L. Zhongwei, Z. Kang, H. Chi, T. Yufei, Advan. In. Materi. Scien. And. Engin. 11, 1 (2016) doi: 10.1155/2016/9520294

18. S. Rana, N. Paul, W. Moira, W. Zhangjian, Struc. And. Civ. Engine. 16, 7 (2016)

19. T.V. Lam, V.D. Tho, V.K. Dien, B.I. Bulgakov, O.V. Aleksandrova, S.I. Bazhenova, $\begin{array}{llll}\text { MATEC. We. } & \text { of.Confe. 251, } 01007 & \text { (2018), }\end{array}$ https://doi.org/10.1051/matecconf/201825101007

20. V. K. Dien, T. V. Lam, Yu. M. Bazhenov, S. I. Bazhenova, O. Yu. Bazhenova, Journal "BST - Bulletin of Construction Equipment" 1, 50 (2019)

21. BS EN 992, Determination of the dry density of lightweight aggregate concrete with open structure (Standard, 10 p) (1996)

22. BSI 1881-122, Testing concrete. Method for determination of water absorption (Standard, 11 p) (2011)

23. S. Rana, N. Paul, W. Zhangjian, MATEC. We. Of. Conf 120, 02010 (2017) doi: 10.1051/matecconf/201712002010

24. BS EN 1352, Determination of static modulus of elasticity under compression of autoclaved aerated concrete or lightweight aggregate concrete with open structure. (Standard, 14 p) (1997)

25. K. Abdullah, M. A. Nasly, M. W. Hussin, N. Nordin, Z. Zakaria, Biol. And. Envir. Engine. 05, 391 (2010) 